\title{
Neuropathic pain after dental treatment
}

\author{
Dental tedaviler sonrası oluşan nöropatik ăgrılar
}

\author{
Neslihan TINASTEPE, Koray ORAL
}

\begin{abstract}
Summary
The head and neck regions are the most common sites of the human body to be involved in chronic pain conditions. Neuropathic pain is a chronic pain condition, and refers to all pain initiated or caused by a primary lesion or dysfunction or transitory perturbation in the peripheral or central nervous system (CNS). Trigeminal neuralgia, atypical odontalgia (phantom tooth pain), burning mouth syndrome, traumatic neuropathies, postherpetic neuralgias and complex regional pain syndrome are neuropathic pain conditions in the orofacial region that can be encountered in pain and dental clinics. The majority of the time this problem is misdiagnosed by the dentist, which can lead to unnecessary treatments. These treatments may include endodontic treatment and extraction of the tooth or teeth in the region. In this review, only post-traumatic peripheral pain neuropathies seen after dental treatments will be discussed.
\end{abstract}

Key words: Nerve injury; neuropathic pain; orofacial pain; posttraumatic neuropathies.

\section{Özet}

Baş ve boyun bölgesi vücudun kronik ăgrılardan en çok etkilenen bölgesidir. Nöropatik ăgrılar, periferal ya da santral sinir sistemindeki primer bir lezyon, disfonksiyon ya da geçici bir bozukluk sonucu başlayan kronik ağrilardan birisidir. Trigeminal nöralji, atipik odontalji (fantom diş ağrisi), yanan ağız sendromu, travmatik nöropatiler, postherpetik nöralji ve kompleks bölgesel ağr sendromu diş ve ağr kliniklerinde karşılaşılabilecek nöpatik orofasial ağrılardandır. Ağız içersinde şikayete neden olan ağrıların bir kısmının nöropatik ağrılar olabileceği hatırlanmadığında yanlış tanı konulmakta ve etkilenen bölgedeki dişlere gereksiz tedaviler yapılmaktadır. Bu yazıda, dental işlemler sonrası ortaya çıkabilen posttravmatik periferal ağrılı nöropatiler tartışıldı.

Anahtar sözcükler: Sinir zedelenmesi; nöropatik ağrl; orofasial ağrl; post-travmatik nöropatiler.

\section{Introduction}

Pain is defined as "an unpleasant sensory and emotional experience associated with actual or potential tissue damage, or terms of such damage". ${ }^{[1]}$ Pain is a displeasing sensation; however, it is a warning symptom against tissue damage and during wound healing. Unlike acute pain, persistent pain has no biological advantage. It is a troublesome malady by itself. The head and neck regions are the most common sites of the human body to be involved in chronic pain conditions. ${ }^{[2,3]}$ Acute, chronic, and recurrent painful conditions are not rare in the orofacial region. In dental practice, pain originating from the teeth and the periodontium, is the most common non-odontogenic pain, although it does occur frequently. ${ }^{[2]} \mathrm{Neu}-$ ropathic pain is a type of chronic pain and is defined as "all pain, initiated or caused by a primary lesion or dysfunction or transitory perturbation in the peripheral or central nervous system (CNS)". ${ }^{[4-6]}$ This 
differs from somatic pain, which occurs in response to noxious stimulation of normal neural receptors. ${ }^{[7]}$

Neuropathic pain may be classified as peripheral or central according to the place where it originates and is divided into episodic and continuous disorders based on symptoms. The episodic neuropathic pain presents as periods of total remission of symptoms whereas the continuous neuropathic pain is an ongoing unremitting pain condition. ${ }^{[8,9]}$

The true prevalence of neuropathic pain is not known. It has been estimated that $1-1.5 \%$ of the general population is affected. The pain that results from spinal cord, brain stem, or thalamic/cortical damage is less common than peripheral neuropathic pain (PNP). ${ }^{[10]}$ Central neuropathic pain (CNP) has been reported in $28 \%$ of multiple sclerosis patients, $75 \%$ of patients with syringomyelia, $60-70 \%$ of patients with spinal cord injury, and $8 \%$ of stroke patients. $^{[11]}$

Trigeminal neuralgia, atypical odontalgia (phantom tooth pain), burning mouth syndrome, traumatic neuropathies, post-herpetic neuralgias and complex regional pain syndrome are the neuropathic pain conditions in the orofacial region that can be encountered in pain and dental clinics. Typically dentists intend to solve the problem with traditional dental treatments which may cause the patient to lose their teeth found the jaw affected. ${ }^{[12]}$

\section{Pathophysiology of neuropathic pain}

Several types of sources, such as vascular compression, radiation, inflammation, trauma, infection, and exposure to neurotoxins to the peripheral nervous system can lead to pathologic damage. ${ }^{[3,13]}$ Demyelination and axotomy (deafferentation with severance of the axon) are the ways to incur these damages. ${ }^{[3]}$ A number of mechanisms have been proposed to explain neuropathic pain conditions, but they are not fully understood. The possible mechanisms in the orofacial region are as follows:

\section{Ectopic impulses from damaged primary afferent nerve fibers}

Axonal injury initiates ectopic activitiy from large and small diameter afferent fibers as well as the cell body in the sensory ganglion in addition to nocicep- tor terminals. In the case of an axotomy, a neuroma can result which can also cause an ectopic discharge. A neuroma is a tangled mass of nervous tissue in conjunction with proliferated Schwann cells. ${ }^{[9,14,15]}$

\section{Ephaptic transmission}

Abnormal connections may occur between or among two or more adjacent demyelinated or unmyelinated axons of damaged nerve. ${ }^{[14,15]}$

\section{Central sprouting}

A-beta afferent fibers sprout into more superficial layers in the dorsal horn making synaptic contacts with nociceptive neurons. ${ }^{[10,14,15]}$

Phenotypical changes in primary afferents and dorsal horn neurons

After nerve injuries, long-term alterations may occur in gene expression such as changes in ionic canal proteins, neurotransmitters, and neurotrophins. ${ }^{[14]}$

\section{Sympathetic nerve activations}

Nerve injury may lead to sympathetic axons sprouting into the dorsal root ganglion where they form baskets around the cell bodies of the sensory neuron and may form a mechanism in which sympathetic activity causes activity in sensory fibers. This hasn't been shown in the trigeminal region yet. ${ }^{[10,14-16]}$

\section{Changes in segmental inhibitory control}

Peripheral nerve injury may reduce the amount of inhibitory control acts through inhibitory interneurons. Large fibers have inhibitory affect on small fibers. When this balance collapses, pain occurs. After nerve injury, large fibers release many excitatory amino acids which can lead to destruction of inhibitory interneurons. ${ }^{[10,14]}$

\section{Central sensitization}

Increased impulses after peripheral nerve injury can cause sensitization in second order neurons in the trigeminal sensory nucleus of the brainstem. Central sensitization can lead to hyperalgesia, spontaneous pain, and allodynia. Diminishments in the effects of descending inhibition control are thought to contribute to central sensitization as well. ${ }^{[14,15,17]}$

Neuronal plasticity, which is the change in function, chemistry and structure of neurons obviously plays 
an important role in the development of neuropathic pain. More than one mechanism can operate in a single patient and these mechanisms may change with time. ${ }^{[10]}$

\section{Clinical characteristics of neuropathic pain}

Despite these instances, neuropathic pain can be initiated by a range of sources varying from local trauma to central nervous system pathologies. ${ }^{[18]}$ They share certain clinical characteristics including:

- Pain quality that is short electrical, lancinating, shooting or sharp in episodic neuropathies with or without stimulus, and a burning character that is present in continuous neuropathies. ${ }^{[9]}$ It should be stated that studies are not unanimous on this issue. ${ }^{[19]}$ Besides these characteristics, aching pain does not preclude the possibility of a neuropathic basis for the patient's pain. ${ }^{[20]}$

- Sensory deficits may accompany the pain. The three main deficits are paresthesia, dysesthesia or anesthesia. Paresthesia is expressed as abnormal, with not necessarily unpleasant sensations such as heaviness, tingling, or numbness. Dysesthesia is regarded as abnormal or unpleasant sensations such as burning, stinging, or stabbing. Anesthesia is total loss of feeling or sensation. ${ }^{[9,21]}$

- There may be a delay in onset after the initial injury/insult (days to months).

- Sympathetic hyperfunction can be detected in clinic examination. ${ }^{[9]}$

These symptoms can be seen in combination in some patients and this can contribute to the complexity of the condition. It is not difficult to differentiate whether or not the pain is neuropathic in origin in the case of the presence of pain accompanied with allodynia and hyperalgesia or resistance to non-steroids and opioids with an apparent history of nerve injury. The problem arises from the absence of definitive evidence of nerve injury. In these cases, quantitory sensory tests QST may helpful. ${ }^{[2]}$

\section{Quantitory sensory testing for neuropathic pain}

Neuropathic pain has a complexity in both the diagnostic and treatment aspects. There are several tests that overcome this issue. These tests enable differentiating the large and small diameter fibers in addition to forming the basis of the most common modalities for the examination and evaluation of trigeminal sensory neuropathy. Touch or proprioceptive stimuli and cold and heat detection thresholds are used for the assessment of the function of A beta fibers, A delta fibers, and thinly unmyelinated fibers respectively. ${ }^{[23,24]}$

The pin-prick test, temperature sensitivity test, static touch detection test, two-point discrimination test, and the direction of movement test are the tests dentists can perform in their clinics for this purpose. ${ }^{[21]}$ These tests provide information regarding peripheral sensory nerve function and help to accurately diagnose patients and can aid in follow-up. ${ }^{[23]}$

\section{Nerve injury}

In order to understand the basis of the classification of nerve injuries in a better way, the organization of the peripheral nerve trunk should be understood. A peripheral nerve is surrounded by connective tissue, specifically epineurium. It contains multiple nerve fascicles. A fascicle is a bundle of several nerve fibers and enclosed by perineurium. A nerve fiber, or axon, is the projection of a nerve cell, encircled by Shwann cells' membrane which is known as the myelin sheath. The supporting tissue around nerve fibers is endoneurium which fills the fascicles. ${ }^{[25-27]}$ After nerve injury, the proximal and distal part of the injured section and cell bodies develop changes according to the severity of the injury. ${ }^{[25-27]}$ Seddon (1943) classified the possible nerve injuries into 3 categories: neuropraxia, axonotmesis, and neurotmesis. ${ }^{[28]}$

In neuropraxia, the endoneurium, perineurium and epineurium are intact. ${ }^{[29]}$ The continuity of the axon is preserved as well as the conduction of nerve impulses from the distal section. ${ }^{[25,29]}$ It is the mildest type of peripheral injury. Recovery time of this type of injury is within days to months, however neuritis and paresthesia may occur. Nerve compression, hematoma, minor stretching and thermal changes are the potential causes of this type of injury. ${ }^{[21]}$ Neuropraxia can be described as a nerve bruise. ${ }^{[25]}$

In axonotmesis, the endoneurium, perineurium 
and epineurium are intact. ${ }^{[29]}$ Wallerian degeneration, which is a process of fragmentation of the axon and myelin sheath, occurs distal to the nerve injury and also proximal to the injury at least first node of the ranvier. Sproutings from the proximal segment spread distally and regenerated axons contact with its peripheral target. ${ }^{[26,27]}$ Recovery time occurs in 2-4 months. Depending on the severity of the injury, complete recovery may not occur. Nerve compression, hematoma, stretching, traction, partial crush, and edema may cause axonotmesis. Paresthesia and episodic dysesthesia are the possible responses to axonotmesis. ${ }^{[21]}$

In neurotmesis, not only the axon, but also the endoneurium, perineurium and epineurium lose their continuity. Since regenerated axons lose their guide to reach their target tissue, some abnormalities such as anesthesia, persistent pain, and neuroma formation may result. Severe traction or complete transection of the nerve are the main causes. ${ }^{[21,25]}$ Full recovery is not possible ${ }^{[25,28]}$ and surgical repair is needed for these cases.

The Seddon's classification was modified by Sunderland (1951) into 5 grades. Two types of injuries were added between axonotmesis and neurotmesis. ${ }^{\text {[29] }}$ MacKinnon and Dellon (1988) described the 6th degree of nerve injury and Birsch and Gidden (1998) classified nerve injury as degenerative and nondegenerative. ${ }^{[30]}$

Incidence of neuropathic pain after dental treatments The terms atypical facial pain, atypical facial neuralgia, atypical odontalgia, dental causalgia, neuropathic orofacial pain, and phantom tooth pain have been used to infer posttraumatic painful peripheral neuropathy in the orofacial region. ${ }^{[22,31]}$ Dental procedures have the potential to cause nerve damage as another type of trauma. Deficits can be transient or permanent depends on the injury. The trigeminal nerve displays a different reaction to injury than other nerves. In proportion to the number of procedures performed, the prevalence of peripheral painful neuropathies are rare after dental treatments. ${ }^{[22]}$

Removal of the third mandibular molar, dental injections, implant treatments, and endodontic treatments are the most common procedures in dentistry that may cause neuropathic conditions. The incidence of nerve injury after these treatment have been reported in the literature but the number of cases resulting in painful neuropathies are not well documented.

After extraction of the third molars due to pericoronitis, periodontal problems, caries, andlor surgeries required for the removal of cysts or tumors may cause injury of the inferior alveolar nerve (IAN), lingual nerve (LN), mylohyoid and buccal nerve. ${ }^{[32]}$ It is reported that $3.6 \%$ of third molar extractions caused temporary deficits and up to $8 \%$ caused permanent deficits in the IAN. ${ }^{[33]}$ The incidence of $\mathrm{LN}$ injuries during third molar removal ranges from $0.2 \%$ to $22 \%$ temporarily and up to $2 \%$ permanently. ${ }^{[34]}$ Several risk factors regarding damage during third molar operations to the IAN and LN have been reported. A close relationship between roots of the third molar and mandibular canal, depth of impaction, surgical techniques such as retraction of lingual flap and surgical experience, use of neurotoxic materials in surgery, and age of the patient can be counted as such factors. ${ }^{[32,35,36]}$

Since there is a detachment of the mucoperiostal flap and removal of bone in the implant surgery, IAN, $\mathrm{LN}$, and mental nerve can be effected and sensation can be altered. ${ }^{[37-39]}$ The incidence of IAN injuries after dental implantation vary from $0-40 \%,{ }^{[40-48]}$ which is the same as other oral surgeries. ${ }^{[37]} 1-8 \%$ of these cases may result in permanent sensory dysfunction. Still, the incidence of persistent pain is not known. ${ }^{[12,38,49,50]}$

IAN can be damaged due to over instrumentation during root canal treatment of the mandibular molar teeth, pressure in the IAN canal from endodontic point or sealant, and the neurotoxic effect of the medication used in the root canal. ${ }^{[51-54]}$ After root canal therapy persistent pain was reported in 3-13\% of cases $^{[55]}$ whilst endodontic surgery ends with painful phantom tooth in $2 \%$ to $3 \%$ of cases. ${ }^{[22,56,57]}$

Supraperiostal or proximal local anesthesia may result in injuries due to direct trauma to the nerve during infiltration of anesthetic solution from the needle, hematoma formation or neurotoxicity from local anesthetic solution to IAN, LN and maxillary 
nerves. However the exact mechanism of these theories is still under debate. Some of the reports indicate that neuropathic pain occurrence after these injuries are between $1: 26,762$ to $1: 800,000^{[58-60]} 34 \%{ }^{[59]}$ and $70 \% \cdot{ }^{[48]}$ It has also been reported that anesthesia or paresthesia can occur in two-thirds of patients with permanent nerve injury involvement, whereas dysesthesia can occur one-third of such patients. ${ }^{[61]}$

Chronic regional pain syndrome (CRPS) which is a neuropathic pain condition in which edema, abnormal skin blood flow, sudumotor activity accompanied with pain are seen very rarely in the head and neck region. Behrman (1949), Jaeger et al. (1986), Saxen and Campbell (1995) reported CRPS after tooth extraction from the molar region. ${ }^{[62-65]}$

In conclusion, neuropathic pain is an abnormal condition of the nervous system which can affect the orofacial region in addition to other parts of the body. It has a very complex pathophysiology and can be initiated by dental treatments such as third molar or implant surgery, endodontic treatments and dental injections.

\section{Conflict-of-interest issues regarding the authorship or article: None declared.}

\section{References}

1. Merskey H. Pain terms: a list with definitions and notes on usage. Recommended by the IASP Subcommittee on Taxonomy. Pain 1979;6(3):249.

2. Donaldson $D$, Kroening $R$. Recognition and treatment of patients with chronic orofacial pain. J Am Dent Assoc 1979;99(6):961-6.

3. Spencer CJ, Gremillion HA. Neuropathic orofacial pain: proposed mechanisms, diagnosis, and treatment considerations. Dent Clin North Am 2007;51(1):209-24.

4. Merskey H, Bogduk N. Classification of chronic pain. 2nd ed. Seattle: IASP Press; 1994.

5. Terminology., IASP (International Association for the Study of Pain) IASP painhttp://www.halcyon.com/iasp/terms-p. html.

6. Vadalouca A, Siafaka I, Argyra E, Vrachnou E, Moka E. Therapeutic management of chronic neuropathic pain: an examination of pharmacologic treatment. Ann N Y Acad Sci 2006;1088:164-86.

7. De Leeuw R. Orofacial pain: guidelines for assessment, diagnosis and management. 4th ed. American Academy of Orofacial Pain. Chicago, IL: Quintessence Books; 2008.

8. Okeson JP. Bell's orofacial pains. 5th ed., Chicago III: Quintessence Pub; 1995. p. 74-5.

9. Benoliel R, Eliav E. Neuropathic orofacial pain. Oral Maxillofac Surg Clin North Am 2008;20(2):237-54, vii.

10. Woolf CJ, Mannion RJ. Neuropathic pain: aetiology, symptoms, mechanisms, and management. Lancet 1999;353(9168):1959-64.

11. Beniczky S, Tajti J, Tímea Varga E, Vécsei L. Evidence-based pharmacological treatment of neuropathic pain syndromes. J Neural Transm 2005;112(6):735-49.

12. Benoliel R, Sharav Y. Chronic orofacial pain. Curr Pain Headache Rep 2010;14(1):33-40.

13. Devor M. Sodium channels and mechanisms of neuropathic pain. J Pain 2006;7(1 Suppl 1):S3-S12.

14. Lund JP, Lavigne GJ, Dubner R, Sessle BJ. Orofacial pain from basic science to clinical management. Quintessence Books, USA: 2001.

15. Attal N, Bouhassira D. Mechanisms of pain in peripheral neuropathy. Acta Neurol Scand Suppl 1999;173:12-24.

16. Fried K, Bongenhielm U, Boissonade FM, Robinson PP. Nerve injury-induced pain in the trigeminal system. Neuroscientist 2001;7(2):155-65.

17. Sessle BJ. Acute and chronic craniofacial pain: brainstem mechanisms of nociceptive transmission and neuroplasticity, and their clinical correlates. Crit Rev Oral Biol Med 2000;11(1):57-91.

18. Lewis MA, Sankar V, De Laat A, Benoliel R. Management of neuropathic orofacial pain. Oral Surg Oral Med Oral Pathol Oral Radiol Endod 2007;103 Suppl:S32.e1-24.

19. Jensen TS, Baron R. Translation of symptoms and signs into mechanisms in neuropathic pain. Pain 2003;102(1-2):1-8.

20. Osterberg A, Boivie J, Holmgren H, Thuomas K-A, Johansson I. The clinical characteristics and sensory abnormalities of patients with central pain caused by multiple sclerosis. In: Gebhart GF, Hammond DL, Jensen TS, editors. Progress in pain research and management. Seattle: IASP Press; 1994. p. 789-96.

21. Misch CE, Resnik R. Mandibular nerve neurosensory impairment after dental implant surgery: management and protocol. Implant Dent 2010;19(5):378-86.

22. Bennett GJ. Neuropathic pain in the orofacial region: clinical and research challenges. J Orofac Pain 2004;18(4):281-6.

23. Eliav E, Gracely RH, Nahlieli O, Benoliel R. Quantitative sensory testing in trigeminal nerve damage assessment. J Orofac Pain 2004;18(4):339-44.

24. Jääskeläinen SK. The utility of clinical neurophysiological and quantitative sensory testing for trigeminal neuropathy. J Orofac Pain 2004;18(4):355-9.

25. Waldram M. Peripheral nerve injuries. Trauma 2003;5:79.

26. Evans GR. Peripheral nerve injury: a review and approach to tissue engineered constructs. Anat Rec 2001;263(4):396-404.

27. Flores AJ, Lavernia CJ, Owens PW. Anatomy and physiology of peripheral nerve injury and repair. Am J Orthop (Belle Mead NJ) 2000;29(3):167-73.

28. Seddon JJ. Three types of nerve injury. Brain 1943;66:237-40.

29. Sunderland S. A classification of peripheral nerve injuries produced by a loss of function. Brain 1952;74:491-505.

30. Birch R, Giddins G. 1998. Peripheral nerve injuries.In: Foy, Fagg eds. Medicolegal reportingin orthopaedic trauma. Edinburgh: Churchill Livingstone.

31. Zakrzewska JM. Classification issues related to neuropathic trigeminal pain. J Orofac Pain 2004;18(4):325-31.

32. Blondeau F, Daniel NG. Extraction of impacted mandibular third molars: postoperative complications and their risk factors. J Can Dent Assoc 2007;73(4):325.

33. Valmaseda-Castellón E, Berini-Aytés L, Gay-Escoda C. Inferior alveolar nerve damage after lower third molar surgi- 
cal extraction: a prospective study of 1117 surgical extractions. Oral Surg Oral Med Oral Pathol Oral Radiol Endod 2001;92(4):377-83.

34. Renton $T$, Hankins $M$, Sproate $C$, McGurk M. A randomised controlled clinical trial to compare the incidence of injury to the inferior alveolar nerve as a result of coronectomy and removal of mandibular third molars. Br J Oral Maxillofac Surg 2005;43(1):7-12.

35. Loescher AR, Smith KG, Robinson PP. Nerve damage and third molar removal. Dent Update 2003;30(7):375-80, 382

36. Benediktsdóttir IS, Wenzel A, Petersen JK, Hintze H. Mandibular third molar removal: risk indicators for extended operation time, postoperative pain, and complications. Oral Surg Oral Med Oral Pathol Oral Radiol Endod 2004;97(4):438-46.

37. Ellies LG, Hawker PB. The prevalence of altered sensation associated with implant surgery. Int J Oral Maxillofac Implants 1993;8(6):674-9.

38. Gregg JM. Neuropathic complications of mandibular implant surgery: review and case presentations. Ann R Australas Coll Dent Surg 2000;15:176-80.

39. Worthington P. Injury to the inferior alveolar nerve during implant placement: a formula for protection of the patient and clinician. Int J Oral Maxillofac Implants 2004;19(5):731-4.

40. Hegedus F, Diecidue RJ. Trigeminal nerve injuries after mandibular implant placement--practical knowledge for clinicians. Int J Oral Maxillofac Implants 2006;21(1):111-6.

41. Hillerup S, Jensen R. Nerve injury caused by mandibular block analgesia. Int J Oral Maxillofac Surg 2006;35(5):437-43.

42. Delcanho RE. Neuropathic implications of prosthodontic treatment. J Prosthet Dent 1995;73(2):146-52.

43. Rubenstein JE, Taylor TD. Apical nerve transection resulting from implant placement: a 10-year follow-up report. J Prosthet Dent 1997;78(6):537-41 .

44. Wismeijer D, van Waas MA, Vermeeren Jl, Kalk W. Patients' perception of sensory disturbances of the mental nerve before and after implant surgery: a prospective study of 110 patients. Br J Oral Maxillofac Surg 1997;35(4):254-9.

45. Bartling R, Freeman K, Kraut RA. The incidence of altered sensation of the mental nerve after mandibular implant placement. J Oral Maxillofac Surg 1999;57(12):1408-12.

46. Walton JN. Altered sensation associated with implants in the anterior mandible: a prospective study. J Prosthet Dent 2000;83(4):443-9.

47. von Arx T, Häfliger J, Chappuis V. Neurosensory disturbances following bone harvesting in the symphysis: a prospective clinical study. Clin Oral Implants Res 2005;16(4):432-9.

48. Renton T. Prevention of iatrogenic inferior alveolar nerve injuries in relation to dental procedures. SADJ 2010;65(8):3424, 346-8, 350-1.

49. Cheung LK, Lo J. The long-term clinical morbidity of mandib- ular step osteotomy. Int J Adult Orthodon Orthognath Surg 2002;17(4):283-90.

50. Walton JN. Altered sensation associated with implants in the anterior mandible: a prospective study. J Prosthet Dent 2000;83(4):443-9.

51. Knowles Kl, Jergenson MA, Howard JH. Paresthesia associated with endodontic treatment of mandibular premolars. J Endod 2003;29(11):768-70.

52. Nitzan DW, Stabholz A, Azaz B. Concepts of accidental overfilling and overinstrumentation in the mandibular canal during root canal treatment. J Endod 1983;9(2):81-5.

53. Fanibunda K, Whitworth J, Steele J. The management of thermomechanically compacted gutta percha extrusion in the inferior dental canal. Br Dent J 1998;184(7):330-2.

54. Pogrel MA. Damage to the inferior alveolar nerve as the result of root canal therapy. J Am Dent Assoc 2007;138(1):65-9.

55. Polycarpou N, Ng YL, Canavan D, Moles DR, Gulabivala K. Prevalence of persistent pain after endodontic treatment and factors affecting its occurrence in cases with complete radiographic healing. Int Endod J 2005;38(3):169-78.

56. Marbach JJ, Hulbrock J, Hohn C, Segal AG. Incidence of phantom tooth pain: an atypical facial neuralgia. Oral Surg Oral Med Oral Pathol 1982;53(2):190-3.

57. Reinhilde J, De Geyseleer C, Van Loven K, De Laat A, Lambrechts $P$, van Steenberghe D. Appearance of painful or nonpainful phantom tooth after tooth extraction. J Dent Res 1998;77:1008.

58. Campbell RL, Parks KW, Dodds RN. Chronic facial pain associated with endodontic therapy. Oral Surg Oral Med Oral Pathol 1990;69(3):287-90.

59. Pogrel MA, Thamby S. Permanent nerve involvement resulting from inferior alveolar nerve blocks. J Am Dent Assoc 2000;131(7):901-7.

60. Haas DA, Lennon D. A 21 year retrospective study of reports of paresthesia following local anesthetic administration. J Can Dent Assoc 1995;61(4):319-20, 323-6, 329-30.

61. Smith MH, Lung KE. Nerve injuries after dental injection: a review of the literature. J Can Dent Assoc 2006;72(6):559-64.

62. Behrman S. Facial neuralgias. Br Dent J 1949;86(8):197-203.

63. Jaeger B, Singer E, Kroening R. Reflex sympathetic dystrophy of the face. Report of two cases and a review of the literature. Arch Neurol 1986;43(7):693-5.

64. Saxen MA, Campbell RL. An unusual case of sympathetically maintained facial pain complicated by telangiectasia. Oral Surg Oral Med Oral Pathol Oral Radiol Endod 1995;79(4):4558.

65. Melis M, Zawawi K, al-Badawi E, Lobo Lobo S, Mehta N. Complex regional pain syndrome in the head and neck: a review of the literature. J Orofac Pain 2002;16(2):93-104. 